\title{
PKM PADA ANAK USIA SEKOLAH DASAR: MENGEMBANGKAN BUDAYA LITERASI DI LINGKUNGAN TAWANG BRAK DESA TAWANGSARI, KEC. GARUM KAB. BLITAR
}

\author{
Oleh: \\ Fahmi Poernamawatie ${ }^{1)}$ dan Yuli Winarni ${ }^{2)}$ \\ ${ }^{1}$ Fakultas Ekonomi dan Bisnis, Universitas Gajayana Malang \\ email: fahmipoerna@unigamalang.ac.id \\ ${ }^{2}$ Fakultas Ekonomi dan Bisnis, Universitas Gajayana Malang \\ email: yuli_winarni@unigamalang.ac.id
}

Abstract

The purpose of this community service activity is to help children of primary school age get used to writing and reading. This habit is expected to increase children's reading interest and develop their reading literacy culture.

The implementation of this activity is done through various way of exercises, such as: reading exercises, rewriting and retelling. Children are also accustomed to read Al-Qur'an and praying together. Drawing and coloring are also steps taken by the community service team to hone children's creativity. Watching films and entrepreneurship exercises to complement this activity, so that children have broad insights and also practice to improve financial literacy.

Even though this activity still not showing the significant impact to the reading and writing skills of the children, but this activity gives benefits in terms of increasing the interest in reading, writing, and retelling something new. Enterpreneurial skills of some participants have have also created at the end of the activity. To achieve more optimal results, this activities should be done regularly with well-planned schedule.

Keywords: Community Service, Literacy Culture, Writing and Reading Skill, Enterpreunership

\section{PENDAhUluaN}

\subsection{Analisa Situasi}

Hasil penelitian yang dilakukan oleh Kemendikbud RI menunjukkan bahwa hanya $6,06 \%$ siswa Indonesia yang memiliki kemampuan membaca secara baik, 47,11\% cukup, dan 46,83\% memiliki kemampuan membaca yang masih kurang. (Kemdikbud, 2017). Hal ini diartikan oleh Charismiadji bahwa kemampuan membaca siswa Indonesia masih berada pada taraf sekedar membaca dan masih sering mengalami kesulitan dalam pemahaman arti suatu bacaan. Kondisi ini menjadikan kemampuan literasi siswa Indonesia berada pada peringkat 60 dari 61 negara.

Kemampuan membaca dengan pemahamannya yang baik tidak diperoleh dalam waktu yang singkat, namun siswa pasti memerlukan waktu yang panjang untuk bisa membaca dan sekaligus memahaminya dengan baik. Kemampuan membaca beserta pemahaman maknanya yang baik tentu juga tidak terlepas dari minat siswa itu sendiri, dukungan orang tua kepada anak, juga pembiasaan anak dalam kegiatan membaca.

Data statistik dari United Nations of Cultural Organization (UNESCO) pada Tahun 2012 menunjukkan bahwa indeks minat baca di Indonesia baru mencapai 0,001 . Hal ini diartikan bahwa setiap 1.000 (seribu) penduduk, hanya ada seorang saja yang memiliki minsat baca dan menulis.

UNDP juga menguatkan penjelasan tersebut, bahwa angka melek aksara orang dewasa di Indonesia hanya sebesar 65,5\%, sedangkan di Malaysia sudah mencapai $86,4 \%$. Rendahnya budaya literasi di Indonesia ini merupakan salah satu penyebab tertinggalnya pendidikan di Indonesia dibandingkan dengan Negara-negara lainnya.

Demokrasi yang baik tentu memerlukan dukungan masyarakat yang memiliki budaya baca. Demokrasi hanya akan berkembang, bahkan survive, jika para 
warganya adalah pembaca, merupakan individu-individu yang merasa perlu untuk membaca, bukan sekedar pendengar dan gemar berbicara." (Joesoef, 2004).

Lingkungan Tawang Brak adalah salah satu dukuh yang berada di Kelurahan Tawangsari, Kecamatan Garum, Kabupaten Blitar. Letak dari dukuh ini sebenarnya secara geografis tidak terlalu jauh dari Kota Blitar, yakni sekitar 8 (delapan) km.

Mata pencaharian penduduk dukuh ini sebagian besar buruh tani dan pedagang kaki lima atau jualan di pasar tradisonal. Masalah pendidikan anak-anak menjadi terabaikan oleh orangtua, karena orangtua disibukkan dengan bekerja untuk mengais rejeki dalam menopang kebutuhan hariannya.

Situasi seperti itu terlihat jelas di Lingkungan Tawang Brak, Desa Tawangsari RT 03/ RW 06. Anak-anak usia Sekolah Dasar pulang sekolah hampir sama sekali tidak mendapat perhatian dari orangtua, ketika mereka tiba di rumah. Pemandangan yang nampak oleh anak-anak adalah kelelahan di wajah dan tubuh orangtuanya. Keadaan yang seperti ini menyebabkan anak tidak tertarik untuk mengulangi pelajarannya di rumah, dan mereka langsung pergi ke luar rumah hingga menjelang waktu ashar.

Waktu ashar anak-anak berangkat mengaji dan bermain hingga waktu maghrib. Selanjutnya, anak-anak pulang dalam keadaan lelah dan tertidur hingga pagi hari. Orangtua tidak bisa banyak berbuat bagi anak-anaknya. Sebagian besar orang tua berpikir bahwa hal terpenting adalah orangtua mampu untuk menyekolahkan anak ke Sekolah Dasar, anak bisa calistung, tidak buta aksara dan bisa menghitung untuk kebutuhan sehari-hari. Orang tua kurang peduli tentang tingkap pemahaman yang dimiliki oleh anak-anak mereka.

Hal seperti itu menurut Kleden (1999) dinyatakan sebagai masyarakat yang melek aksara pada kelompok pertama. Kelompok ini merupakan masyarakat yang memiliki kemampuan membaca sederhana, dinyatakan telah bebas buta aksara, namun karena akses terhadap bahan bacaan rendah dan minimnya keperluan untuk mempraktikkannya, membuat kemampuan itu berkurang atau bahkan hilang. Kelompok ini secara teknis telah melek aksara, namun secara fungsional dan budaya masih tergolong buta aksara. (Kleden , 1999)

Rutinitas kegiatan yang dilakukan oleh masyarakat di RT 03/ RW 06 tersebut menimbulkan kebiasaan yang kurang baik bagi anak-anak di lingkungan Tawang Brak. Minat baca, dukungan orangtua untuk belajar, keterbatasan tersedianya sumber informasi yang menarik bagi anak-anak, pemanfaatan yang rendah terhadap sumber informasi yang ada merupakan penyebab rendahnya budaya literasi di antara an ak-anak.

Kenyataan memprihatinkan yang juga Nampak pada anak-anak di Lingkungan Tawang Brak adalah beberapa siswa kelas 2 di suatu Sekolah Dasar, belum bisa membaca dan menulis kalimat sederhana dengan baik dan benar. Hal itu dianggap wajar bagi orang tua dan tidak ada beban sama sekali bagi anak dan orangtua atas ketidak pahaman tersebut.

Merujuk pada fakta yang ada, Tim Pengabdian kepada Masyarakat (PkM) menemukan beberapa masalah yang terjadi pada anak usia Sekolah Dasar di Lingkungan Tawang Brak, yaitu: Pertama, kemampuan membaca dan menulis masih sangat kurang. Anak-anak usia Sekolah Dasar yang berada di kelas 2 dan 3 masih mengalami kesulitan untuk menulis dan membaca satu kata yang tersusun dari 2 (dua) atau lebih suku kata, yang suku katanya terdiri dari minimal 3 huruf. Contoh: menyanyikan, menghilangkan, berkunjung. Anak-anak kesulitan menuliskan juga membacanya, akibatnya mereka juga kesulitan untuk memahami makna sebuah kalimat yang terdidir dari kata-kata yang terbangun dari suku kata dengan lebih dari 3 huruf.

Masalah ke dua yang ditemukan oleh tim PkM adalah pada saat anak-anak membaca atau kisah pendek, mereka sulit untuk memahami konten dari kisah tersebut. Mereka yang sudah bisa baca dan tulispun tidak dengan mudah untuk memahaminya. Sebagai contoh: ketika siswa diberi bacaan sebanyak 1 (satu) alinea, kemudian siswa diberi kesempatan untuk membaca 2 (dua) kali, dan diberi pertanyaan sederhana terkait dengan bacaan tersebut, anak-anak kesulitan untuk menjawabnya.

Berikut contoh bacaan sederhana:"Ani adalah anak ke dua dari keluarga Hartono. Ani memiliki seorang abang dan seorang adik yang cantik. Kakak Ani bernama Agus dan 
adik Ani bernama Susi. Mereka tinggal di Surabaya." Pertanyaan yang diberikan adalah 1). Siapakah nama anak pertama dari Keluarga Hartono? 2). Berapakah jumlah anak perempuan dari keluarga Hartono?

Fakta menunjukkan bahwa sebagian besar anak-anak usia Sekolah Dasar kelas 2 dan 3 di Lingkungan Tawang Brak, RT 03/ RW 06, tidak mampu menjawab pertanyaan tersebut, setelah mereka membaca kisah Ani.

Kenyataan lain menunjukkan bahwa anak-anak usia Sekolah Dasar di Lingkungan Tawang Brak, RT 03/ RW 06 memiliki kemampuan yang sangat kurang untuk menuliskan dan menceritakan kembali sebuah kisah yang didengarkan dan diperlihatkan melalui sebuah audio dan video.

Anak-anak terlihat sangat antusias dan menonton dengan semangat mendengarkan dan melihat video/ film kartun kisah Nusan tara. Mereka diberi kesempatan 3 (tiga) kali mendengarkan dan menonton, selanjutnya mereka diminta untuk menuliskan kembali, dan/ atau menceritakan ulang kisahnya. Fakta menunjukkan, tidak ada satupun diantara 7 (tujuh) anak kelas 2 dan 3 di Lingkungan Tawang Brak, RT 03/ RW 06 yang mampu menuliskan dan menceritakan ulang kisah yang sudah didengarkan dan ditontonnya.

\subsection{PERMASALAHAN MITRA}

Berdasarkan survey pendahuluan yang telah dilakukan oleh Tim PkM, beberapa masalah yang dihadapi anak-anak usia Seko lah Dasar, terutama kelas 2 dan 3 di RT 03/ RW 06, Lingkungan Tawang Brak, Kec. Tawangsari, Kab. Blitar meliputi:

1. Kemampuan menulis dan membaca anakanak usia Sekolah Dasar (terutama kelas 2 dan 3) di Lingkungan Tawang Brak, RT 03/ RW 06, Kec. Tawangsari masih rendah;

2. Tingkat pemahaman anak-anak terhadap sebuah kisah yang dibacanya masih sangat kurang;

3. Kemampuan untuk bercerita dan menuliskan kembali sebuah kisah pendek yang baru didengarnya masih sangat rendah.

\section{KAJIAN LITERATUR}

\subsection{Pengertian Literasi}

Literasi dimaknai sebagai istilah umum yang merujuk kepada seperangkat kemampu an dan keterampilan individu dalam membaca, menulis, berbicara, menghitung, dan memecahkan masalah pada tingkat keahlian tertentu yang diperlukan dalam kehidupan sehari-hari. Sehingga, literasi tidak bisa dilepaskan dari kemampuan berbahasa. (https://id.wikipedia.org/wiki/Literasi). Istilah literasi awalnya merujuk pada praktik meulis dan membaca bagi yang melek aksara dan yang masih buta aksara. Perkembangan selanjutnya, literasi dipadankan dengan istilah pengetahuan dan keterampilan dalam berbagai bidang kehidupan.

Jenis literasi dasar ada 6 (enam), yaitu literasi calistung, literasi sains, literasi teknologi informasi dan komunikasi, literasi keuangan, literasi budaya, dan literasi kewar ganegaraan (Jendela Pendidikan dan Kebudayaan, Edisi VI/ Oktober-2016). Hal yang urgen saat ini di Indonesia mencakup literasi membaca, yang diartikan sebagai suatu peristiwa atau kegiatan subjek dalam menggunakan teks atau bahan bacaan (Barton dan Hamilton, 2000; Heath dan Street, 2008).

\subsection{Strategi dalam Literasi Membaca}

Membaca merupakan jantungnya pendi dikan (Farr, 1984). Dengan membaca, masya rakat akan mampu membuka wawasan berpikirnya, dan memiliki pengetahuan yang luas. Proses membaca merupakan proses yang sangat kompleks, memadukan antara daya ingat, daya khayal, pengaturan, penerapan, dan pemecahan masalah.

Berbagai strategi untuk dapat melaku kan literasi membaca antara lain:1). Strategi membaca pemahaman, 2). Strategi membaca cermat, 3). Strategi telling story. Ketiga strategi ini dapat digunakan untuk: 1). Mema hami informasi, focus pada teks bacaan yang ada, 2). Mampu memperoleh pemahaman yang mendalam, dan 3) Mau mendengarkan cerita menarik untuk meningkatkan minat baca pada diri sesorang.

\subsection{Konsep Dasar Budaya Literasi}

Beberapa konsep dasar yang harus diperhatikan dalam literasi antara lain 1). Literasi dini, 2). Literasi dasar, 3) Literasi visual.

Literasi dini merupakan kemampuan menyimak, memahami Bahasa lisan dan berkomunikasi melalui gambar. Literasi dasar merupakan kemampuan bicara, membaca, menulis, menghitung yang terkait dengan 
kemampuan analisis untuk memperhitungkan, mempersepsikan informasi, mengomunisasikan, serta menggambarkan informasi berdasarkan pemahaman dan pengambilan kesimpulan pribadi.

Literasi visual adalah pemahaman lanjutan melalui pengembangan kemampuan belajar dengan pemanfataan materi visual dan audio visual. Literasi visual melibatkan keluarga, lingkungan, serta pendidikan formal.

\subsection{Model Pengembangan Budaya Literasi}

Pengertian budaya seringkali disinonimkan dengan tradisi, yang diartikan sebagai sikap dan kebiasaan masyarakat yang Nampak dari perilaku sehari-hari. Sikap dan kebiasaan ini memerlukan internalisasi buda ya, agar bisa tahan lama.

Proses internalisasi dilakukan melalui proses menanamkan dan menumbuhkan suatu nilai atau budaya, hingga menjadi bagian dari diri seseorang. Penanaman nilai dilakukan dengan berbagai metode seperti pendidikan, pengarahan, indoktrinasi. (Dhara, 1997: 82)

Pengembangan budaya literasi meru pakan kegiatan yang terkait dengan peme liharaan, penyempurnaan, dan pe-ningkatan, misal minat baca anak-anak, yang dilakukan secara terus menerus.

Salah satu upaya yang dapat dilakukan untuk mengembangkan budaya literasi yaitu melalui pembiasaan dan dilanjutkan dengan tahap pengembangan, yang disertai dengan pengembangan keterampilan produktif. (Abidin, dkk: 2018: 279).

Lipton dan Deborah (2016: 132 menyatakan bahwa ada 3 (tiga) tahapan pelak sanaan gerakan literasi, yaitu: 1). Pembiasaan, 2). Pengembangan, dan 3). Pembelajaran.

Pembiasaan dimaksudkan untuk menumbuhkan minat terhadap bacaan dan kegiatan membaca dalam diri anak. Pembiasaan ini bisa diawali dengan kegiatan membaca selama 15 (lima belas) menit dalam sehari, selanjutnya dapat ditingkatkan, ketika anak sudah terbiasa.

Pembiasaan bisa ditunjang dengan penyediaan sarpras, seperti area baca yang nyaman, buku bacaan yang menarik, audio visual, pembuatan bahan bacaan oleh anak sendiri.

Pengembangan minat baca dimaksud kan untuk meningkatkan kemampuan literasi yang bertujuan untuk mengembangkan kemampuan memahami suatu bacaan yang dikaitkan dengan pengalaman pribadi, berpikir kritis, mengolah kemampuan komunikasi secara kreatif melalui kegiatan menanggapi bacaan. (Andarson dan Krathwohl, 2010)

Pembelajaran dimaksudkan untuk meningkatkan kemampuan literasi di semua mata pelajaran dengan menggunakan buku bacaan pengayaan. Tujuan dari pembelajaran adalah mengembangkan kemampuan memahami teks.

\section{METODE}

Pelaksanaan PkM melibatkan 10 (sepuluh) sampai dengan 15 (lima belas) anak usia Sekolah Dasar yang ada di Lingkungan Tawang Brak RT 03/ RW 06, Desa Tawangsari, Kec. Garum, Kab. Blitar.

Tim PkM akan melatih anak-anak melalui 2 (dua) tahapan, yaitu tahap pembia saan dan tahap pengembangan. Tahap pembiasaan dilakukan dengan cara sebagai berikut:

a. Minggu ke 1: Anak-anak diberi bacaan singkat dan ringan sebanyak 2 (dua) eks. untuk dibaca berulang-ulang;

b. Minggu ke 2: Anak-anak diminta menuliskan kembali isi dari bacaan yang telah dibaca dengan bahasanya sendiri;

c. Minggu ke 3: Anak-anak diminta untuk membacakan hasil tulisannya yang telah dibuat pada minggu ke 2;

d. Minggu ke 4: Ana-anak diminta untuk memvisualisasikan bacaan yang telah dibaca dengan membuat gambar sederhana dan diwarnai;

e. Minggu ke 5: Anak-anak diminta untuk menceritakan ulang konten dari gambar yang telah dibuat pada minggu ke 4 dengan bahasanya sendiri;

f. Minggu ke $6-10$ : Tim melakukan evaluasi dengan cara mengadakan lomba untuk beberapa kegiatan yang telah dilaksanakan pada minggu ke 1 sampai dengan minggu ke 5 .

Setiap pertemuan memerlukan waktu 90 (sembilan puluh) menit dengan kegiatan dan durasi waktu pelaksanaanya sebagai berikut:

Hari Sabtu:

a. 15.30 - 15.40: Senam pemanasan;

b. $15.40-16.20$ : Kegiatan inti;

c. 16.20 - 16.30: Isma (istirahat dan makan) 


\section{d. 16.30 - 16.40: Nonton film kartun Nusantara}

e. 16.40 - 17.00: Mengaji;

f. $17.00-17.30$ : Bermain/ belajar mewarna dan persiapan shalat maghrib

g. $17.30-18.00$ : Shalat maghrib berjamaah Dzikir, berdo'a bersama

Hari Minggu:

Anak-anak dilatih untuk berwirausaha, sebagai cara untuk membudayakan literasi keuangan. Anak-anak diminta untuk main jualan, ada yang sebagai penjual dan pembeli. Uang dan barang dagang (kue untuk anakanak) disediakan oleh Tim PkM. Anak-anak yang diminta untuk membelanjakan uang yang dibawanya sesuai dengan keinginannya. Kue yang dibeli oleh anak-anak boleh dimakannya.

Si penjual diminta untuk menghitung besar penghasilannya dan laba yang diperolehnya. Selanjutnya, baik pembeli dan penjual diminta untuk membuat catatan keuangannya.

\section{HASIL DAN PEMBAHASAN}

\subsection{Hasil}

Foto kegiatan PkM menunjukkan hasil pelaksanaan $\mathrm{PkM}$ di Lingkungan Tawang Brak RT 03/RW06, Ds. Tawangsari, Kec. Garum, Kab. Blitar.

Kegiatan PkM menempati rumah ahli waris dari almarhumah Ibu Subandiya Farida.

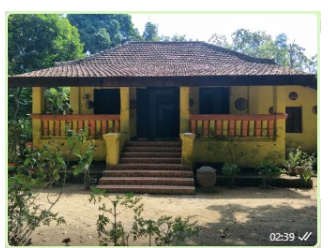

Gambar 1:

Rumah Tempat

Kegiatan PkM

Gambar 2:

Nonton Film

Kartun

Nusantara
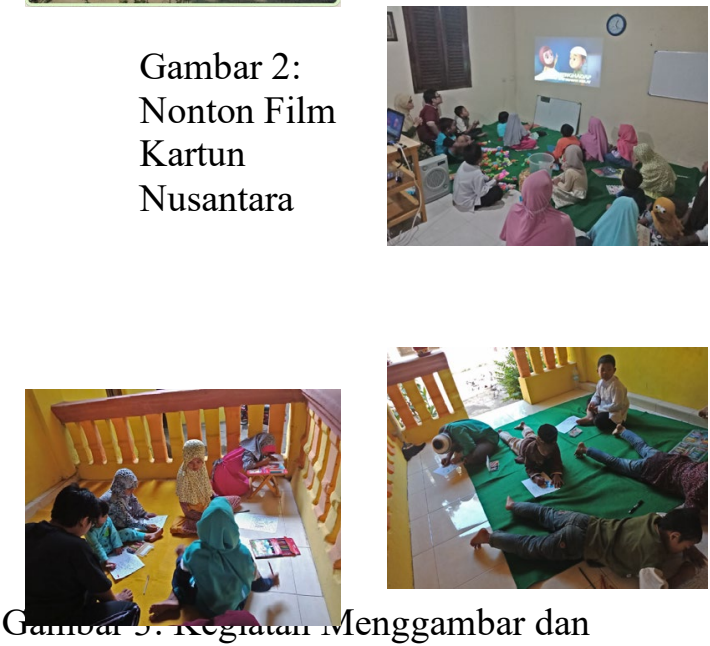

Mewarna
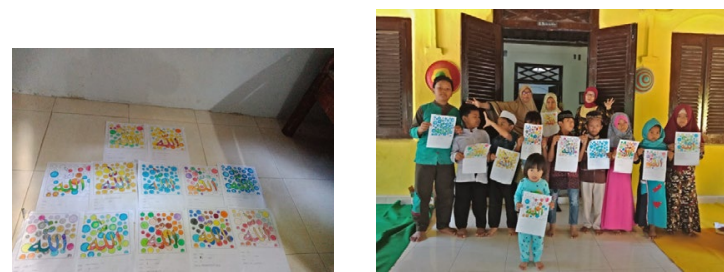

Gambar 4: Hasıl Ivenggambar dan Mewarna (Dilnmhakan)

Gambar 5:

Bermain bersama dan Mengaji
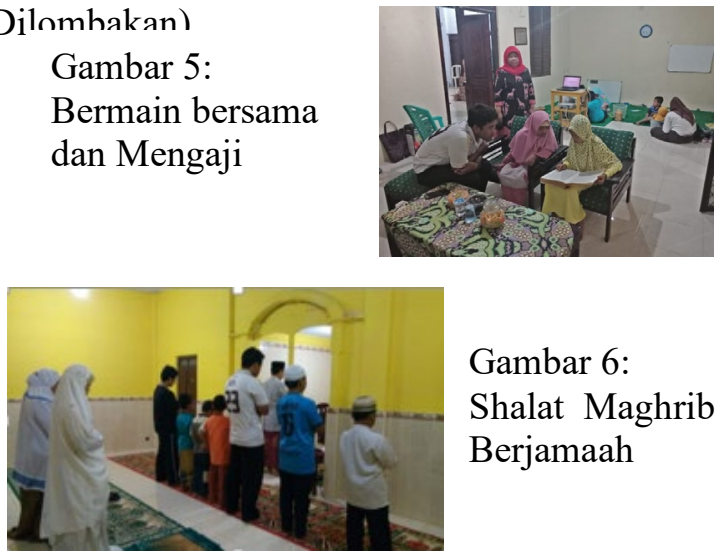

Gambar 6:

Shalat Maghrib

Berjamaah

Dari kegiatan pertama, yaitu Nonton

Film Kartun Nusantara, anak-anak peserta kegiatan diminta untuk: 1) menuliskan butirbutir yang dianggap penting oleh mereka; 2) menceritakan ulang secara lisan tentang apa yang dilihat dan didengarkannya. Kegiatan ini dimaksudkan untuk meningkatkan daya ingat dan daya nalar anak, serta mengajarkan anak supaya berani beropini di depan audience (Gambar 2). Secara rata-rata, anak-anak kelas 4 sd. 5 telah dapat dan berani bercerita ulang dengan lancar didepan anak-anak yang lain. Sedangkan, untuk anak-anak kelas 1 sd. 3, mereka masih kelihatan malu-malu dalam bercerita lisan didepan temannya, namun secara tertulis, mereka dapat menceritakan butir-butir penting yang ada dalam sebuah kisah.

Kegiatan kedua yaitu Menggambar dan Mewarna. Kegiatan menggambar dan mewarna dikerjakan oleh anak-anak kelas 5 dan 6 serta, sedangkan anak-anak kelas 1 sd. 4 hanya mewarna. Kegiatan ini untuk meningkatkan kemampuan motorik anak dan daya imajinasi serta kreativitas anak. Kegiatan ini dilombakan dan diberi hadiah, bagi yang mendapatkan nilai terbesar (Gambar 3). Secara umum, hasil menmggambar dan mewarna masih standard dan perlu ditingkatkan melalui pemberian latihan secara terus menerus (Gambar 4).

Kegiatan lainnya adalah mengaji dan bermain. Anak-anak juga diajarkan mengaji (bagi siswa kelas 1 sd. 3) dan menghafal suratsurat pendek dalam Al-Qur'an bagi siswa kelas 4 sd. 6. Kegiatan ini dimaksudkan untuk membentuk karakter religius anak-anak, 
meningkatkan keimanan dan ketaqwaan mereka terhadap Sang Pencipta. (Gambar 5). Secara umum, anak-anak sudah bisa dan biasa mengaji di rumahnya. Namun, untuk kegiatan hafalan surat-surat pendek, anak-anak belum pernah berlatih. Hasil dari kegiatan PkM di bidang hafalan ini adalah, sebanyak 2 orang anak dapat menghafalkan 7 (tujuh) surat pendek, seorang hafal 10 (sepuluh) surat pendek, dan seorang telah hafal 13 (tiga belas) surat pendek.

Untuk menghilangkan kejenuhan mereka, anak-anak diberi waktu untuk bermain, sesuai dengan pilihannya. Permainan lego dan balok susun disiapkan untuk mengasah kreativitas mereka dalam membuat suatu bentuk produk tertentu, sesuai imaginasinya. Selanjutnya, mereka diminta untuk menjelaskan kepada teman-temannya yang lain untuk produk yang telah dibuatnya. (Gambar 5)

Kegiatan hari Sabtu diakhiri dengan shalat maghrib berjamaah dan do'a bersama. Imam dari shalat berjamaah adalah Bapak Ir. H. Moh. Ischaq (Gambar 6). Anak-anak diajarkan untuk membiasakan berdzikir dengan kalimat thayibah selepas melaksanakan shalat fardhu.

Pada hari Minggunya, bagi anak-anak yang tidak memiliki kegiatan dengan keluarganya, diminta datang kembali untuk latihan kegiatan kewirausahaan. Pada latihan awal ini, uang untuk membeli dan barang dagang masih berasal dari tim pengabdi. Barang dagang berupa kue basah sederhana. Harga per produk tidak lebih dari Rp. 3.000,00. Anakanak kelas 4 sd. 6 berperan sebagai penjual, mereka diajarkan untuk menghitung harga pokoknya, yang selanjutnya digunakan sebagai dasar menenentukan harga jualnya. Anak-anak kelas 1 sd. 3 berperan sebagai pembeli, setiap anak diberi uang Rp. 5.000,00.

Setiap penjual dibekali dengan uang receh, sebagai saldo awalnya sebesar Rp. 3.000,00. Di akhir kegiatan ini, setiap anak harus membuat catatan keuangan tentang: 1) Berapa uang yang dibelanjakan dan berapa sisannya; 2) Berapa hasil penjualan; 3) Berapa laba yang diperoleh; 4). Berapa uang tunai yang ada di setiap penjual. Penjual harus dapat menjual semua produknya dan pembeli harus dapat membelanjakan uangnya seefisien mungkin dengan hasil yang memuaskan. Kegiatan berlatih untuk berwirausaha ini ditutup dengan makan kue bersama yang telah dibeli oleh para pembeli.
Kegiatan berlatih berwirausaha ini dimaksudkan untuk melatih setiap anak untuk dapat berpikir dan bertindak produktif dan meminimkan tindakan konsumtif. Selain itu, anak-anak dilatih untuk membiasakan diri dalam belanja seperlunya untuk memenuhi kebutuhan dan keinginannya. Mereka dilatih untuk mengendalikan dirinya dalam mengelola uang dan bisa belajar meng-create money dan meng-alocate money dengan sebaik-baiknya. Kegiatan ini juga dimaksudkan agar anak-anak terbiasa untuk melakukan pencatatan keuangan di setiap kegiatan yang melibatkan keuangan.

\subsection{Pembahasan}

Kegiatan ini memiliki sasaran bagi anak-anak kelompok usia sekolah dasar untuk memperoleh berbagai pengetahuan dan ketrampilan dan pembiasaan dalam berliterasi aksara seperti membaca, menulis, bercerita. Selain itu juga memiliki kemampuan dalam berliterasi keuangan, seperti keinginan berwirausaha, menentukan harga jual, meren canakan laba, dan mencatat atas transaksi yang terjadi.

Sasaran penting lainnya adalah memberikan bekal kepada anak-anak untuk tetap menjadi insan yang beriman, bertaqwa, serta patuh terhadap menjalankan ajaran agamanya. Hal ini dimaksudkan untuk membangun insan yang berkarakter baik sejak dini

Hasil yang sukses atas kegiatan yang dilaksanakan pada kegiatan pengabdian kepada masyarakat ini belum dapat dilihat secara instan, karena kegiatan ini harus dilakukan secara kontinu, terus menerus, rutin, dan mendapat dukungan besar dari orang tua dan lingkungan keluarga serta masyarakat setempat, termasuk lingkungan sekolahnya.

Hasil dari kegiatan PkM ini sudah dapat memberikan manfaat bagi anak-anak untuk menambah pengetahuan, wawasan, dan ketrampilan berbagai hal dengan beberapa latihan yang diberikan.

\section{SIMPULAN DAN SARAN}

\subsection{Simpulan}

Simpulan dari kegiatan pengabdian kepada masyarakat ini meliputi:

- Kegiatan yang dilaksanakan pada PkM merupakan kegiatan dalam peningkatan kemampuan, kemauan, dan peningkatan 
pengetahuan yang merupakan tindakan aplikatif yang sangat penting dalam upaya untuk memperoleh peningkatan berbagai pengetahuan dan keterampilan bagi anakanak usia sekolah dasar;

- Para peserta yang terdiri dari anak-anak usia sekolah dasar memiliki antusiasme yang besar dalam mengikuti kegiatan ini dan mereka memiliki motivasi yang sangat tinggi untuk mengikuti semua kegiatan yang dialksanakan tim pengabdi selama kegiatan PkM. Hal ini terlihat dari keinginan anak-anak untuk selalu mengikuti kegiatan sampai pelaksanaan program ini selesai, dan bahkan anak-anak selalu bertanya tentang keberlanjutan program ini.

- Hasil pengamatan atas pelaksanaan kegiatan ini dapat dilihat bahwa secara rata-rata, anak-anak dapat mengikuti dan dengan hati gembira melaksanakan instruksi dari pengabdi dengan antusias dan cukup baik.

\subsection{Saran-saran}

Untuk memberikan hasil yang lebih baik terhadap hasil kegiatan PkM ini di masa mendatang, maka pengabdi memberikan saran sebagai berikut:

- Sebaiknya, para orangtua dan anak-anak saling memotivasi putra/i nya dan temannya untuk selalu belajar dalam meningkatkan pengetahuan, wawasan dan keterampilan dan melakukan latihanlatihan yang diperlukan;

- Sebaiknya ada orangtua atau pamong yang bisa menginisiasi kegiatan serupa bagi anak-anak, agar anak-anak dapat terus berlatih dan memperdalam serta memperoleh keterampilan yang lain, diluar latihan yang telah diperoleh selama kegiatan PkM;

- Dengan selesainya kegiatan pengabdian kepada masyarakat ini diharapkan agar pemamngku kepentingan di wilayah ini dapat lebih mempererat hubungan dan kerja sama dengan Universitas Gajayana Malang, dan barangkali bisa dilakukan atau dikembangkan kerjasama lanjutan dengan Program Studi yang lain, seperti Program Studi Psikologi, dan lainnya.

\section{REFERENSI}

Abidin, Yunus, Tita Mulyati dan Hana Yunansah. (2018). Pembelajaran Literasi: Strategi Meningkatkan Kemampuan Literasi Matematika, Sains, Membaca, dan Menulis. Jakarta: Bumi Aksara

Anderson, L.W dan Krathwohl, 2010. Kerangka Landasan untuk Pembela jaran, Pengajaran dan Asesmen (Revisi Taksonomi

David Barton, Mary Hamilton, dan Roz Ivanič (ed.). 2000. Situated Literacies: Reading and Writing in Context. London dan New York: Routledge

Dhara, Talizhidu. 1997. Budaya Organisasi, Jakarta: Rineka Cipta

Farr, R. 1984. Reading: Trends an Challenges. Washington D. C.: National Education Association

Heath, Shirley Brice dan Brian V. Street. 2008. On Ethnography: Approaches to Language and Literacy Research. New York: Teachers College Press bekerja sama dengan National Conference on Research in Language and Literacy (NCRLL)

Joesoef, Daoed. 2004. Bukuku Kakiku. Jakarta: Gramedia Pustaka Utama

Kemdikbud, P. (2017). Hasil Indonesian National Assesment Programme (INAP). Retrieved March 11, 2019, Puspendik.kemdikbud.go.id website: https://puspendik.kemdikbud.go.id/inap$\underline{\mathrm{sd} /}$

Kleden, Ignas. 1999. "Buku di Indonesia: Perspektif Ekonomi Politik tentang Kebudayaan", bunga rampai dalam Alfons Taryadi [ed.]. 1999. Buku dalam Indonesia Baru. Jakarta: Yayasan Obor Indonesia.

Lipton, Laura dan Deborah Hubble. (2016). Sekolah Literasi Perencanaan dan Pembinaan. Bandung: Nuansa Cendekia Publishing \& Printing

Pendidikan Bloom). Yogyakarta: Pustaka Pelajar

https://id.wikipedia.org/wiki/Literasi, Diakses 11 Januari 2021 
